\title{
PENGARUH PEMANFAATAN TEKNOLOGI, KOMPETENSI SUMBER DAYA MANUSIA DAN KOMITMEN ORGANISASI TERHADAP KUALITAS LAPORAN KEUANGAN SKPA PROVINSI ACEH
}

\author{
Rian Rezky Pratama*1, M. Rizal Yahya ${ }^{* 2}$ \\ ${ }^{1,2}$ Program Studi Akuntansi Fakultas Ekonomi dan Bisnis Universitas Syiah Kuala \\ e-mail: rianpratama000@gmail.com ${ }^{* 1}$,rizal_yahya@ unsyiah.ac.id ${ }^{* 2}$
}

\begin{abstract}
The research examines the influence of The Use of Information Technology (PT), Human Resources Competence (SDM) and Organizational Commitment (KO) on the Quality of the financial statements (KLK). The population in this study is SKPA of Aceh Province. The sampling technique used is simple random sampling. This study uses primary data which obtained through the questionnaire results. The data were colleccted 63 questionnaires from 35 SKPA. Data were processed using SPSS version 22 and analyzed using multiple linear regression, F-Test, and t-test. The results show that simultaneously, The Use of Information Technology (PT), Human Resources Competence (SDM) and Organizational Commitment (KO) affect the Quality of the financial statements (KLK). Partially, each independent variable affect Quality of the financial statements.
\end{abstract}

Keywords: The Use of Information Technology, Human Resources Competence, Organizational Commitment, Quality of the financial statements

\section{Pendahuluan}

SAP menjadi landasan bagi setiap Pemda dalam membuat laporan keuangannya. Hasil dari laporan ini menjadi sebuah bentuk tanggungjawab terhadap kinerja dan pengelolaan keuangan setiap pemda kepada publik maupun kepada instansi yang berada di atasnya. Pembuatan sebuah standar akuntansi bagi pemerintah diyakini mampu untuk menjelaskan pengelolaan keuangan bagi setiap instansi pemerintahan dalam pelaksanaan visi dan misi dalam meningkatkan kesejahteraan masyarakat. Peraturan Menteri No.71 Tahun 2010 menjadi dasar perundangan yang digunakan tentang SAP tersebut.

Laporan keuangan bagi pemerintah daerah juga disusun dalam satu tahun anggaran, yang dimana laporan ini sering disebut juga sebagai LKPD. LKPD tersusun dari laporan-laporan seperti LRA, Neraca, LAK, CaLK. Menurut Wati (2014: 1), laporan keuangan menjadi sebuah cerminan dalam mengetahui setiap kegiatan instansi pemerintah yang dijalankan ataupun yang direncanakan. Sifat relevan, bisa diperbandingkan, mudah dipahami dan juga andal menjadi sebuah syarat mutlak dalam penyusunan laporan keuangan.

Pemerintah Provinsi Aceh, yang dimana menjadi subjek penelitian penulis berhasil meraih opini WTP pada tahun 2015 dan 2016. Namun demikian, dari hasil audit tersebut juga masih ditemukan berbagai permasalahan, seperti pada penataan persediaan keuangan pada Satuan Kerja Perangkat Aceh (SKPA), pengelolaan terhadap aset tetap yang masih belum sesuai dengan standar, pengelolaan dana bos yang masih belum tepat sasaran, pembayaran premi terhadap asuransi JKRA juga belum menggunakan data kependukukan yang valid, serta terdapat lebih bayar terhadap beberapa proyek infrastruktur (Aceh. Tribunnews.com: 2017). Tabel 1.1 dapat dilihat opin yang diberikan BPK terhadap Pemprov Aceh mulai tahun 2012 hingga 2016.

Tabel 1.1

Opini BPK Tahun 2012-2016

\begin{tabular}{|c|c|c|c|c|c|}
\hline Pemerintah & \multicolumn{5}{|c|}{ Opini BPK } \\
\cline { 2 - 6 } Daerah & 2012 & 2013 & 2014 & 2015 & 2016 \\
\hline Aceh & WDP & WDP & WDP & WTP & WTP \\
\hline
\end{tabular}

Sumber: BPK RI

Pemanfaatan atas teknologi tidak hanya digunakan pemerintah daerah dalam menyusun laporan keuangan namun juga digunakan untuk memberikan informasi terhadap lapo ran tersebut. Informasi yang terkandung mencerminkan penggunaan atas sumber daya yang dimiliki dan juga 
akuntabilitas yang telah dilaksanakan oleh pemerintah daerah. Peraturan Pemeritah Nomor 59 Tahun 2005 menyatakan bahwa informasi yang dihasilkan sangat diperlukan dalam menindaklanjuti setiap proses-proses yang berhubungan dengan pembangunan dan juga sebagai bentuk terlaksananya pengelolaan pemerintahan yang baik (good governence). Dengan demikian, pemanfaatan serta pengembangan teknologi menjadi sebuah kewajiban pemerintah daerah untuk dijalankan dalam membentuk suatu sistem informasi dan sistem manajemen yang lebih terpadu dan sederhana.

Laporan keuangan juga tidak lepas dari Sumber Daya Manusia (SDM) pada proses penyusunannnya. Tingkat kompetensi bagi SDM khususnya yang memiliki fungsi dan tugas dalam hal yang berkaitan dengan pelaporan keuangan penting untuk diperhatikan dan juga dikembangkan. Dalam suatu instansi pemerintah, tuntutan akan penyelenggaraan akuntansi pemerintahan menjadi suatu tugas penting sehingga laporan tersebut menghasilkan laporan yang berstandar atas akuntansi pemerintahan yang berlaku. Wati (2014) menyatakan kompetensi yang dimiliki suatu SDM berpengaruh signifikan terhadap kualitas LKPD. Namun Syarifudin (2014) pada penelitiannya menemukan bahwa kompetensi yang dimiliki suatu SDM tidak memiliki pengaruh terhadap kualitas LKPD.

Wujud dalam tercapainya visi dan misi sebuah organisasi, sebuah komitmen dalam organisasi menjadi sebuah peranan yang sangat penting. Komitmen organsisasi secara umum terbagi atas tiga kompenen yang saling melengkapi, yaitu: komitmen afektif, normatif dan berkelanjutan (Kreitner dan Kinicki, 2013:165). Setiap individu yang berada di suatu entitas dapat dinilai komitemennya untuk tetap menjadi anggota dari suatu entitas tersebut. Individu yang berkomitmen kuat terhadap organisasi cenderung memiliki ketersediaan untuk mempertahankan keanggotaannya dan tetap berkomitmen terhadap pencapaian dari tujuan entitasnya. Pembentukan komitmen khususnya dalam organisasional sebaiknya dibangun atas dasar kepercayaan terhadap nilai-nilai yang dianut dalam suatu entitas tersebut, sifat rela dan juga loyalitas terhadap entitas yang dinaunginya. Komitmen organisasi juga pada umumnya menghasilkan sebuah rasa untuk saling memiliki bagi setiap individu terhadap entitasnya. Maksyur (2015) menyatakan, komitmen organisasi memiliki pengaruh terhadap kualitas LKPD. Dengan kata lain, komitmen orgnisasi dapat mejadi sebuah tolak ukur dalam melakukan peniliain terhadap tingkat kualitas suatu LKPD yang dihasilkan.

\section{Kerangka Teori dan Perumusan Hipotesis}

IAI (2012: 1) menyatakan laporan keuangan memberikan gambaran mengenai posisi keuangan sebuah perusahaan secara tersruktur dan menggambarkan kinerja atas keuangan dari sebuah perusahaan. Laporan keuangan menyajikan beberapa informasi berkaitan dengan keuangan perusahaan seperti: posisi keuangan, arus kas, serta kinerja keuangan. Informasi yang dihasilkan dan terkandung didalamnya menjadi landasan dalam pembuatan keputusan yang bersifat ekonomis bagi pihak yang berkepentingan. Selain itu, laporan keuangan menjadi bentuk dari tanggungjawab manajemen dalam menggunakan sumber daya yang terlah diberikan.

Pemerintah daerah juga memiliki sebuah bentuk tanggungjawabnya berupa Laporan Keuangan Pemerintah Daerah (LKPD). LKPD merupakan fase terakhir dalam proses akuntansi yang diselenggarakan oleh pemerintah daerah. Menurut Silviana (2013), pertanggugjawaban pemerintah dearah terhadap masyarakat atas pengelolaan dana publik dapat dilihat dan tergambar dalam pelaporan keuangan yang dihasilkan. Tingkat keandalan dan kualitas sebuah laporan pengelolaan keuangan tergambar dari informasi-informasi yang dimiliki oleh laporan tersebut, memiliki sifat dapat dipahami, bebas dari multitafsir, bebas dari kesalahan material, dapat dibandingkan dan juga menjadi sebuah landasan dalam pengambilan keputusan (Yosefrinaldi, 2013). Informasi yang terkandung dari suatu LKPD tidak hanya berguna bagi pemerintah pusat maupun masyarakat, namun laporan keuangan ini juga dapat digunakan bagi para pihak lain seperti investor untuk menilai perkembangan suatu daerah. Informasi dimilili suatu laporan keuangan dapat dikatakan bermanfaat apabila mampu mempengaruhi pihak berkepentingan dalam pengambilan keputusan yang menjadi sasarannya dan memiliki tingkat pemahaman yang mudah dipahami.

Teknologi merupakan sebuah alat yang memudahkan manusia dalam membentuk suatu sistem informasi. Menurut Mulyadi (2010: 5) sebuah sistem 
informasi yang menggunakan komputer, terdiri dari komponen penting berikut: komputer, auxiliary storage, telekomunikasi dan juga perangkat lunak. Dalam peggunaannya, Darwanis dan Mahyani (2009) menyebutkan bahwa teknologi dapat memproses, menjalankan, menyimpan dan mengakses informasi yang dimiliki secara mudah dan kemudian menghasilkan informasi sesuai dengan yang dibutuhkan serta disampaikan kepada para pengguna yang membutuhkan dalam sistem pengendali atas sebuah sistem yang berlaku. Pengembangan terhadap sistem informasi ini juga memerlukan perpaduan dari berbagai disimplin ilmu, seperti: ilmu pengetahuan terhadap sistem komputer, sistem informasi, pengetahuan terhadap perancangan dan pengetahuan terhadap penerapan seluruh sistem sehingga menghasilkan informasi yang diperlukan. Lebih jauh lagi, informasi yang diperlukan tersebut dapat disebarkan melalui teknologi.

Penggunaan dan juga pemanfaatan terhadap teknologi dapat menjadi peningkat dalam kualitas informasi yang dihasilkan oleh sebuah laporan. Namun penggunaan sistem teknologi, khususnya komputer juga memiliki berbagai kekurangan. Yosefrinaldi (2013) menyatakan, sebuah sistem yang menggunakan komputer memiliki sifat yang tidak fleksibel dan tidak dapat mampu untuk beradaptasi dengan cepat saat terjadi sebuah perubahan pada suatu sistem yang sudah berjalan, perencanaan dan pembuatan ulang sistem yang baru cenderung memakan waktu serta biaya yang mahal dan juga membutuhkan sebuah sistem kontrol yang baik.

Pemanfaatan terhadap sebuah teknologi dalam melaksanakan sebuah sistem maupun pelaksanaan sistem secara tetap membutuhkan sumber daya manusia di dalamnya. Hal ini membuktikan bahwa SDM menjadi sebuah modal yang penting dalam pelaksanaan seluruh kegiatan (Fathoni, 2006: 8). Mengembangkan sumber daya khususnya SDM memerlukan sebuah analisis yang berkelanjutan dan juga pengembangan terhadap kompetensi-kompetensi yang dimiliki sehingga dapat dimaksimalkan demi kepentingan organisasi ataupun kepentingan individu.

Sebuah tingkat kompetensi menjadi sebuah dasar bagi setiap individu dalam menciptakan kinerja yang baik dalam setiap tugas yang diemban. Tingkat efisiensi, keefektifan dan keekonomisan dalam melaksanakan suatu pekerjaan dapat dilihat dari kompetensi SDM yang dimiliki. Dalam pembuatan maupun penyusunan laporan keuangan, kompetensi atas pengetahuan terhadap standar akuntansi yang berlaku dan kompetensi terkait persoalan keuangan menjadi sebuah syarat penting demi tercapainya waktu yang tepat dan juga pelaporan keuangan yang baik.. Mardiasmo (2002: 146) menyatakan, "semakin cepat sebuah laporan disajikan maka pengambilan keputusan akan semakin baik".

Komitmen sikap dan juga komitmen tingkah laku merupakan dua dasar pembentuk komitmen organisasi. Komitmen sikap menunjukkan keadaan suatu individu dalam mementingkan nilai dan juga tujuan pribadi sesuai dengan tujuan organisasi dan juga memiliki keinginan untuk mempertahankan keanggotannya. Komitmen tingkah laku digambarkan dengan hasrat yang dimiliki oleh suatu individu dalam menetapkan untuk terus terikat dengan organisasi. Lebih jauh lagi, Allen dan Mayer (1991) telah melakukan penelitan secara multidimensional yang dimana mendifinisikan bahwa komitmen organisasi menjadi sebuah kondisi piskologis yang menunjukkan hubungan antara pekerja dan organisasi yang dimana mempunyai pengaruh dalam keputusan untuk melanjutkan keanggotannya di dalam organisasi tersebut.

Rasa keterlibatan bagi seorang karyawan dalam melaksanakan tujuan organisasinya merupakan salah satu bentuk komitmen organisasi yang dimana rasa keterlibatan ini dapat meningkatkan pengolahan informasi. Hahn (1992) dalam penelitiannya menyatakan bahwa komitmen yang tinggi yang dimiliki oleh sesorang, akan bersedia memberi waktu yang lebih dalam memproses sebuah informasi dan deskripsi yang diberikan. Hal ini menunjukan keterlibatan anggota yang tinggi dalam sebuah organisasi menjadi sebuah alternatif dalam meningkatkan komitmen organiasi.

Pembentukan sebuah komitmen organisasi yang baik juga akan menghasilkan sebuah rasa ikut memiliki bagi para individu yang berada pada sebuah entitas. Individu yang memiliki rasa terikat kepada nilai-nilai organisasi akan lebih bertanggugjawab dalam melaksanakan segala kegiatan yang berkaitan dengan organisasi dan juga menjadi sebuah motivasi untuk melaporkan semua aktivitasnya yag dimana hal ini berarti terciptanya sebuah akuntabilitas. 


\section{Pemanfaatan teknologi terhadap kualitas laporan keuangan}

Pemerintah menerbitkan PP No. 56 Thn 2005 yang menyatakan, "pemerintah daerah memiliki kewajiban untuk melakukan pemanfaatan terhadap penggunaan teknologi". Pemanfaatan teknologi bagi pemerintah daerah tidak lepas dari tanggungjawab yang diberikan untuk membuat pelaporan keuangan yang andal dan tepat waktu. Selain pemanfaatan terhadap teknologi, pmerintah daerah juga diwajibkan melakukan pengembangan terhadap teknologi dan juga memanfaatkan kemajuan teknologi yang terus mengalami pertumbuhan. Sehingga pembuatan laporan keuangan dan juga penyaluran informasi atas LKPD dapat diakses oleh publik.

Penggunaan teknologi khususnya teknologi komputer, mampu melakukan pemrosesan dan penyimpanan informasi dengan mudah. Penggunaan teknologi komputer juga dapat digunakan sebagai suatu bentuk alat komunikasi dalam membantu menyebarkan informasi. Kemampuan teknologi pada saat ini sangat membantu kegiatan manusia (Indriasari dan Nahartyo, 2008).Meskipun demikian, Yosefrinaldi (2013) juga menyebutkan bahwa teknologi memiliki sebuah kelemahan, yang dimana antara lain seperti susahnya adaptasi sistem komputer apabila terjadi perubahan sistem yang dimana perubahan ini membutuhkan waktu untuk menyesuaikan kembali dan penggunaan teknologi ini pada umumnya memiliki biaya pemasangan yang tidak murah. Zuliarta (2012) menyatakan, "pemanfaatan teknologi memiliki pengaruh yang positif dan signifikan terhadap kualitas LKPD”. Hal ini juga ditemui Zuliarta (2012) dalam penelitiannya. Pada penelitian ini, peneliti mengharapkan hasil yang sama dengan penelitianpenelitian terdahulu.

3. Pemanfaatan teknologi berpengaruh terhadap kualitas laporan keuangan

\section{Sumber daya manusia terhadap kualitas laporan keuangan}

Wiley (2002) dalam Azhar (2007) menemukan bahwa SDM merupakan dasar bagi organisasi dan juga menjadi penggerak dalam setiap kegiatan organisasi yang mencakup visi, misi dan tujuan. SDM juga menjadi salah satu faktor penting dalam pelaporan keuangan. UU No. 43 Thn 1999 menjadi sebuah landasan bagi pemerintah dalam menentukan tugas- tugas pokok bagi para pegawainya (PNS). PNS dalam suatu entitas pemerintahan merupakan SDM yang dimilikioleh entitas tersebut. Sehingga pembentukan SDM yang berkualias menjadi tugas dan tanggungjawab bagi setiap entitas pemerintah. Hal ini diperlukan agar setiap SDM yang dimiliki oleh entitas pemerintah memiliki kemampuan dalam pelaksanaan tugas-tugas dan tanggungjawab yang diberikan kepadanya. Tidak hanya itu, latar belakang pendidikan, pengalaman dan pelatihan yang memadai juga dapat menjadikan SDM memiliki kompetensi yang baik (Kharis, 2010 dalam Arfianti, 2011).

SDM menjadi suatu elemen penting dalam sebuah organisasi yang dimana dapat dipastkan jika pengelolaan SDM harus diperlukan pengelolaan yang baik. Pengelolaan keuangan yang dilakukan oleh pemerintah daerah terkhusus oleh SKPD juga pada dasarnya harus memiliki SDM yang berkulitas, berlatar belakang yang sesuai dengan job desk yang diemban dan juga memiliki pemahaman akuntansi dan pengalaman pada bidang keuangan pada khususnya bagi para pegawai yang bertanggungjawab dalam penyusunan laporan keuangan. Semua hal ini diperlukan agar penyelenggaran atas sebuah sistem akuntabilitas yang telah ditetapkan oleh pemerintah dapat berjalan dengan baik. Menurut Warisno (2009) dalam Arfianti (2011) mengatakan bahwa kegagalan SDM dalam menerapkan konsep akuntansi akan memiliki dampak terhadap kandungan informasi yang keliru.

H2. Sumber daya manusia berpengaruh terhadap kualitas laporan keuangan.

\section{Komitmen organisasi terhadap kualitas laporan keuangan}

Nilai-nilai yang dimiliki oleh organisasi dapat menjadi alasan bagi para individu yang berada dalam suatu orgnisasi untuk dapat mempercayai organisasi tersebut yang kemudian menghasilkan sebuah komitmen organisasi. Selain itu, kerelaan pekerja dalam membantu organisasi dalam pencapaian tujuan serta loyalitas untuk menjadi anggota organisasi juga merupakan hal yang penting untuk terus dikembangkan dan dijaga.

Ramadhan (2015) menyatakan komitmen organisasi dapat mempegaruhi kualitas sebuah laporan keuangan. Dengan kata lain, seorang pegawai atau aparatur negara yang berkomitmen tinggi akan 
memberikan output yang lebih baik. Selain Ramadhan (2015) juga bahwa faktor komitmen organisasi berpengaruh terhadap kualitas informasi yang dihasilkan dalam pelaporan keuangan, dengan kata lain dapat dikatakan apabila pegawai atau apratur negara memiliki komitmen terhadap organiasi yang tinggi, maka informasi atas pelaporan keuangan yang dihasilkan akan lebih berkualitas.

H3. Komitmen organisasi berpengaruh terhadap kualitas laporan keuangan.

\section{Metode Penelitian}

\section{Sampel dan Data}

Penelitian yang dilakukan bertujuan untuk menguji hipotesis dan bersifat kausalitas. SKPA menjadi populasi penelitian dengan jumlah sampel yang digunakan berjumlah 70 pegawai pada 35 SKPA yang masing-masing diwakilkan oleh dua (2) pegawai bidang keuangan. Data yang dihasilkan dan juga digunakan dalam melakukan analisis pada penelitian menggunakan data primer dan dihasilkan melalui menyebarkan kuesioner.

\section{Operasionalisasi Variabel}

Variabel-variabel yang digunakan dalam penelitian ini adalah:

- Variabel bebas: Pemanfaatan Teknologi (PO), SDM, Komitmen Organisasi (KO)

- Variabel terikat: Kualitas Laporan Keuangan (KLK)

Dari Tabel 3.1 di bawah dapat dilihat pengoperasionalan dan juga pengukuran setiap variabel-variabel yang menjadi dasar dalam penelitian ini.

Tabel 3.1

Operasional Variable

\begin{tabular}{|c|c|c|}
\hline Variabel & Indikator & Skala \\
\hline \multicolumn{3}{|c|}{ Variabel Dependent } \\
\hline $\begin{array}{l}\text { Kualitas } \\
\text { Laporan } \\
\text { Keuangan }\end{array}$ & $\begin{array}{ll}\text { 1. } & \text { Relevan } \\
\text { 2. Andal } \\
\text { 3. Dapat dibandingkan } \\
\text { 4. } \quad \text { Dapat dipahami } \\
\text { (PP No. } 71 \text { Tahun 2010) }\end{array}$ & Interval \\
\hline \multicolumn{3}{|c|}{ Variabel Independent } \\
\hline $\begin{array}{l}\text { Pemanfaatan } \\
\text { Teknologi }\end{array}$ & $\begin{array}{l}\text { 1) Pemanfaatan teknologi komputer dan jaringan } \\
\text { 2) Pengembangan terhadap penggunaan teknologi } \\
\text { 3) Maintance dan penggunaan teknologi secaramaksimal }\end{array}$ & Interval \\
\hline $\begin{array}{l}\text { sumber daya } \\
\text { manusia }\end{array}$ & $\begin{array}{ll}\text { 1. } & \text { Tanggung jawab } \\
\text { 2. } & \text { Latar belakang pendidikan } \\
\text { 3. } & \text { Pengalaman } \\
\text { 4. } & \text { Pelatihan } \\
\text { 5. } & \text { Efisiensi }\end{array}$ & Interval \\
\hline $\begin{array}{l}\text { Komitmen } \\
\text { organisasi }\end{array}$ & $\begin{array}{ll}\text { 1. } & \text { Affective commitment } \\
\text { 2. } & \text { Continuance } \\
\text { 3. } & \text { Normative commitment }\end{array}$ & Interval \\
\hline
\end{tabular}

Sumber: Data Primer, Diolah (2019)

\section{Metode Analisis dan Rancangan Pengujian Hipotesis \\ Uji Validitas dan Reliabilitas}

Pengukuran terhadap validitas suatu kuesioner perlu untuk dilakukan. Maka penelitian ini juga melakukan pengujian terhadap validitas kuesioner yang digunakan. Tingkat validitas suatu kuesioner dapat dilihat dari total skor konstruksinya (Ghozali, 2011:68).
Pengukuran terhadap reliabilitas jawaban informan yang dihasilkan juga merupakan hal yang penting untuk dilakukan. Reliabilitas pada penelitian ini didasarkan terhadap nilai Cronbach Alpha yang dihasilkan tiap instrumen. Menurut Ghozali (2013:47) "kuesioner reliabel jika Cronbach Alpha lebih besar dari $0,60 . "$ 


\section{Uji Asumsi Klasik}

Penggunaan metode analisis regresi berganda pada penelitian mewajibkan peneliti untuk melakukan pengujian asumsi klasik. Berikut uji-uji asumsi klasik yang dilakukan peneliti pada penelitian ini:

1. Tingkat Normalitas

Tingkat normalitas atau uji normalitas dilakukan untuk melihat pendistribusian variabel-variabel yang digunakan. Ghozali (2013:160) menyatakan, "sebuah model regresi dapat dikatakan baik apabila data yang dihasilkan memiliki distribusi normal ataupun mendekatinya."

2. Uji Multikolonieritas

Tingkat korelasi antar variabel bebas dapat dilihat dan diuji menggunakan uji multikolonieritas. Model yang bebas terhadap multikolonieritas merupakan sebuah model yang baik untuk digunakan dalam penelitian. Ghozali (2013: 105) menyatakan, "korelasi yang bebas multikolonieritas memiliki nilai VIF yang lebih besar dari 10 atau memiliki nilai tolerance < $0,10 . "$

3. Uji Heteroskedastisitas

Pengujian ini digunakan untuk melihat sifat heteroskedastisitas yang dimiliki sebuah model, model penelitian yang baik tidak memiliki sifat heteroskedastisitas dan memiliki nilai residual yang tidak berubah antar pengamatan. Menurut Ghozali (2013:139), sebuah model tidak memiliki sifat heteroskedastisitas jika grafik yang dihasilkan oleh bantuan program SPSS tidak menghasilkan suatu pola tertentu. Hal ini dapat dilihat melalui scatterplot yang dihasilkan dengan dihasilkan antara nilai prediksi ZPRED dan SPRESID.

\section{Uji Hipotesis}

Pengujian hipotesis dilakukan dengan melakukan analisa terhadap data yang dihasilkan dengan menggunakan metode regresi linear berganda.

$$
\mathrm{Y}=\mathrm{a}+\mathrm{b} 1 \mathrm{X} 1+\mathrm{b} 2 \mathrm{X} 2+\mathrm{b} 3 \mathrm{X} 3+\mathrm{e}
$$

\section{Dimana:}

\begin{tabular}{|c|c|}
\hline Y & = Kualitas laporan keuangan \\
\hline a & $=$ Konstanta \\
\hline $\mathrm{b} 1, \mathrm{~b} 2$ & = Koefisien Regresi \\
\hline $\mathrm{X} 1$ & $=$ Pemanfaatan teknologi \\
\hline $\mathrm{X} 2$ & $=$ Sumber daya manusia \\
\hline $\mathrm{x} 3$ & $=$ Komitmen organisasi \\
\hline & $=$ Error terms \\
\hline
\end{tabular}

\section{Pengujian Hipotesis Secara Simultan (Uji F)}

Ghozali (2013: 177) menyatakan, "pengujian simultan (Uji F) bertujuan untuk melihat tingkat pengaruh variabel independen terhadap variabel dependen secara bersamaan

\section{Pengujian Hipotesis Secara Parsial (Uji t)}

Ghozali (2013: 178) menyatakan, "uji t dilakukan untuk melihat pengaruh yang dihasilkan tiap variabel bebas terhadap variabel terikat."

\section{Koefisien Determinasi (Adjusted $\mathbf{R}^{2}$ )}

Tingkat kemampuan suatu model dalam menjelaskan variabel dependennya diukur dengan menggunakan koefisien determinasi. Penelitian ini menggunakan Adjusted-R2 dalam pengukuran koefisien determinasi yang dihasilkan. Ghozali (2011: 97) menyatakan, "sebuah model yang memiliki nilai Adjusted-R2 yang tinggi maka semakin tinggi variabel indepen dapat menjelaskan variasi variabel dependen."

\section{Hasil Dan Pembahasan}

\section{Pengujian Validitas dan Reliabilitas \\ Uji Validitas}

Uji validitas merupakan alat ukur tingkat validitas instrumen yang digunakan. Uji Pearson Product- Moment Coefficient of Correlations digunakan dalam peneliti ini dengan tingkat signifikansi 5\%. Dari Tabel 4.2 dapat dijelaskan bahwa variabel KLK yang terdiri atas sembilan(9) butir pertanyaan, variabel PT yang terdiri dari tujuh(7) butir pertanyaan, variabel SDM yang terdiri dari delapan(8) butir pertanyaan, variabel KO yang terdiri dari dua belas (12) adalah valid.

\section{Uji Reliabilitas}

Sarjono dan Julianta (2011: 45) menyatakan, "apbila nilai Cronbach Alpha > 0,60 maka suatu indikator variabel dikatakan reliabel." Dari Tabel 4.2 dibawah dapat dilihat bahwa masing-masing variabel yang digunakan dalam penelitian ini memiliki nilai Cronbach Alpha yang lebih besar dari 0,60 dengan masing-masing variabel memiliki nilai Cronbach Alpha sebesar:
- KLK
$: 0,601$
- $\mathrm{PT}$
$: 0,777$
- SDM
$: 0,879$
- $\mathrm{KO}$
$: 0,760$ 
Tabel.4.2

Hasil Pengujian Validitas dan Reliabilitas

\begin{tabular}{|c|c|c|c|c|c|c|}
\hline \multirow[t]{2}{*}{ No } & \multirow[t]{2}{*}{ Variabel } & \multirow{2}{*}{$\begin{array}{c}\text { Butir } \\
\text { Pertanyaan }\end{array}$} & \multicolumn{2}{|c|}{ Validitas* } & \multirow{2}{*}{$\begin{array}{c}\text { Reliabilitas* } \\
\text { Cronbach Alpha }\end{array}$} & \multirow[t]{2}{*}{ Ket. } \\
\hline & & & $\begin{array}{c}\mathrm{R} \\
\text { Hitung }\end{array}$ & Ket. & & \\
\hline \multirow[t]{9}{*}{1.} & \multirow[t]{9}{*}{ Kualitas Laporan Keuangan (Y) } & $\mathrm{Y}_{1}$ & 0,443 & \multirow{9}{*}{ Valid } & \multirow{9}{*}{0,601} & \multirow{9}{*}{ Reliabel } \\
\hline & & $\mathrm{Y}_{2}$ & 0,430 & & & \\
\hline & & $\mathrm{Y}_{3}$ & 0,468 & & & \\
\hline & & $\mathrm{Y}_{4}$ & 0,501 & & & \\
\hline & & $\mathrm{Y}_{5}$ & 0,441 & & & \\
\hline & & $\mathrm{Y}_{6}$ & 0,518 & & & \\
\hline & & $\mathrm{Y}_{7}$ & 0,619 & & & \\
\hline & & $\mathrm{Y}_{8}$ & 0,615 & & & \\
\hline & & $\mathrm{Y}_{9}$ & 0,348 & & & \\
\hline \multirow[t]{7}{*}{2.} & \multirow{7}{*}{$\begin{array}{l}\text { Pemanfaatan teknologi } \\
\text { (X1) }\end{array}$} & $\mathrm{X} 1_{1}$ & 0,585 & \multirow{7}{*}{ Valid } & \multirow{7}{*}{0,777} & \multirow{7}{*}{ Reliabel } \\
\hline & & $\mathrm{X} 1_{2}$ & 0,625 & & & \\
\hline & & $\mathrm{X} 1_{3}$ & 0,771 & & & \\
\hline & & $\mathrm{X} 1_{4}$ & 0,757 & & & \\
\hline & & $\mathrm{X} 1_{5}$ & 0,653 & & & \\
\hline & & $\mathrm{X} 1_{6}$ & 0,557 & & & \\
\hline & & $\mathrm{X} 1_{7}$ & 0,619 & & & \\
\hline \multirow[t]{8}{*}{3.} & \multirow{8}{*}{$\begin{array}{l}\text { Komptensi sumber daya manusia } \\
\text { (X2) }\end{array}$} & $\mathrm{X} 2_{1}$ & 0.316 & \multirow{8}{*}{ Valid } & \multirow{8}{*}{0,879} & \multirow{8}{*}{ Reliabel } \\
\hline & & $\mathrm{X} 2_{2}$ & 0.474 & & & \\
\hline & & $\mathrm{X} 2_{3}$ & 0.363 & & & \\
\hline & & $\mathrm{X} 2_{4}$ & 0.386 & & & \\
\hline & & $\mathrm{X} 2_{5}$ & 0.542 & & & \\
\hline & & $\mathrm{X} 2_{6}$ & 0.528 & & & \\
\hline & & $\mathrm{X} 2_{7}$ & 0.647 & & & \\
\hline & & $\mathrm{X} 2_{8}$ & 0.647 & & & \\
\hline \multirow[t]{11}{*}{4.} & \multirow[t]{11}{*}{ Komitmen organisasi (X3) } & $\mathrm{X} 3_{1}$ & 0.554 & \multirow{11}{*}{ Valid } & \multirow{11}{*}{0,760} & \multirow{11}{*}{ Reliabel } \\
\hline & & $\mathrm{X} 3_{2}$ & 0.646 & & & \\
\hline & & $\mathrm{X} 3_{3}$ & 0.386 & & & \\
\hline & & $\mathrm{X} 3_{4}$ & 0.597 & & & \\
\hline & & $\mathrm{X} 3_{5}$ & 0.403 & & & \\
\hline & & $\mathrm{X} 3_{6}$ & 0.512 & & & \\
\hline & & $\mathrm{X} 3_{7}$ & 0.447 & & & \\
\hline & & $\mathrm{X} 3_{8}$ & 0.440 & & & \\
\hline & & $\mathrm{X} 3_{9}$ & 0.482 & & & \\
\hline & & $\mathrm{X} 3_{10}$ & 0.651 & & & \\
\hline & & $\mathrm{X} 3_{11}$ & 0.680 & & & \\
\hline
\end{tabular}

Sumber: Data Primer, Diolah (2019)

\section{Pengujian Asumsi Klasik}

\section{Uji Normalitas}

Uji normalitas diperlukan dalam melihat pendistribusian data yang dihasilkan oleh variabelvariabel. Uji Kolmogrov-Smirnov merupakan pengujian yang digunakan pada penelitian ini yang dimana penghitungan normal atau tidaknya suatu distribusi data yang dimiliki dilihat berdasarkan tingkat nilai Kolmogrov-Smirnov yang dihasilkan.
Distribusi dikatakan normal apabila nilai KolmogrovSmirnov > 0,05.

Tabel 4.3

Hasil Uji Normalitas

\begin{tabular}{|l|r|}
\hline \multicolumn{2}{|c|}{ One-Sample Kolmogrov-Smirnov Test } \\
\hline Kolmogrov-Smirnof Z & .073 \\
\hline Asymp. Sig. (2-tailed) & .200 \\
\hline
\end{tabular}




\section{Uji Multikolonieritas}

Korelasi antar variabel bebas yang digunakan dapat dilihat melalui uji multikolonieritas. Uji ini dapat diukur dengan melihat nilai VIF yang dihasilkan dan juga nilai tolerance yag dihasilkan oleh masingmasing variabel. Pengukuran ini dilakukan dengan melakukan perbandingan yang dimana apabila nilai VIF yang dihasilkan lebih besar daripada 10 dan nilai tolerance lebih kecil dari 0,10 maka terjadi sifat multikolonieritas.

Tabel 4.4

Hasil Uji Multikolonieritas

\begin{tabular}{|c|l|l|c|c|c|}
\hline \multicolumn{2}{|l|}{ Variabel } & \multicolumn{2}{|c|}{$\begin{array}{c}\text { Colollinearity } \\
\text { Statistic }\end{array}$} \\
\hline Dependen & \multicolumn{2}{|l|}{ Independen } & Tolerance & VIF \\
\hline Y & $\begin{array}{l}\text { Kualitas } \\
\text { Laporan } \\
\text { Keuangan }\end{array}$ & $\mathrm{X} 1$ & $\begin{array}{l}\text { Pemanfaatan } \\
\text { Tekonologi } \\
\text { Sumber } \\
\text { Daya } \\
\text { Manusia } \\
\text { Komitmen } \\
\text { Organisasi }\end{array}$ & .774 & 1.291 \\
X3 & .638 & 1.566 \\
\hline
\end{tabular}

Sumber: Data Diolah (2019

Tabel 4.4 menggambarkan bahwa masingmasing variabel yang digunakan memiliki nilai tolerance yang lebih besar daripada 0,1 dan memiliki nilai VIF lebih kecil dari 10. Masing-masing variabel memiliki besaran nilai tolerance dan VIF sebesar:

- $\mathrm{X} 1$ : tolerance $=0,775 ; \mathrm{VIF}=1.291$

- $\mathrm{X} 2$ : tolerance $=0,773 ; \mathrm{VIF}=1.365$

- $\mathrm{X} 3$ : tolerance $=0,638 ; \mathrm{VIF}=1.566$

Dengan demikian dapat disimpulkan bahwa variabelvariabel bebas dari sifat multikolonieritas.

\section{Heteroskedastisitas}

Pengujian heteroskedastisitias juga diperlukan untuk menilai sebuah meodelregresi yang digunakan. Sebuah regresi yang baik untuk digunakan dalam penelitian harus memiliki sifat homoskedastisitas. Ghozali (2013: 139) menyatakan: "variasi residual yang dihasilkan dari antara tiap pengamatan memiliki hasil yang tetap". Pengujian yang dilakukan pada penelitian ini didasarkan kepada nilai ZPRED dengan nilai SRESID pada sebuah scatterplot dengan menggunakan bantuan program SPSS. Pengujian ini akan menghasilkan sebuah pola yang bebas, jika sebuah model yang digunakan memiliki sifat homoskedastisitas.

\section{Gambar 4.1}

Hasil Uji Heteroskedastisitas

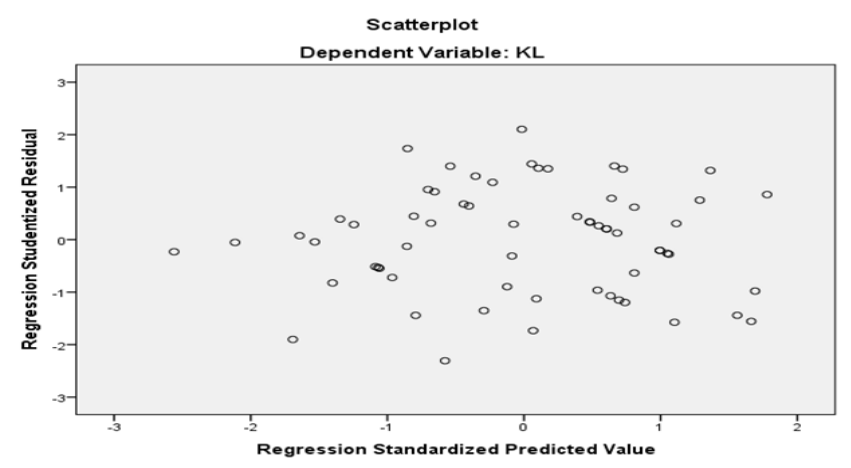

Sumber: Data Diolah (2019)

Dari gambaran scatterplot di atas dapat diketahui bahwa hasil dari pengujian yang dilakukan memiliki penyebaran yang tidak memiliki pola tertentu. Hasil ini menunjukkan bahwa variabel yang digunakan terbebas dari sifat heteroskedastisitas.

\section{Hasil Pengujian Hipotesis}

Uji hipotesis dilakukan untuk menguji hipotesis awal yang telah diajukan. Pengujian ini dianalisis menggunakan regresri linear berganda. Dalam menghasilkan persamaan dan penganalisisa, peneliti menggunakan bantuan program SPSS. Berikut hasil regresi yang dihasilkan pada penelitian ini.

Tabel 4.5

Hasil Pengujian Regresi Linear Berganda

\begin{tabular}{|c|c|c|c|c|c|}
\hline Model & \multicolumn{2}{|c|}{$\begin{array}{c}\text { unstandardized } \\
\text { coefficients }\end{array}$} & $\begin{array}{c}\text { Standardized } \\
\text { coefficients }\end{array}$ & \multirow{2}{*}{ Sig. } & \\
\cline { 2 - 4 } & $\mathrm{B}$ & Std.error & Beta & & \\
\hline $\begin{array}{c}\text { (constant) } \\
\text { X1 }\end{array}$ & 16,492 & 3,085 & & 5,346 &, 000 \\
\hline X2 & .254 & .079 & .326 & 3.203 & .002 \\
\hline X3 & .173 & .073 & .332 & 3.181 & .002 \\
\hline
\end{tabular}

Sumber: Data Diolah (2019)

Persamaan regresi yang dihasilkan dapat memberikan informasi bahwa, konstansa yang dimiliki pada persamaan ini adalah sebesar 16,492 yang dimana nilai konstanta ini menggambarkan bahwa variabel pemanfaatan teknologi (X1), kompetensi SDM (X2),dan komitmen organisasi (X3) jika memiliki nilai yang konstan, besaran terhadap kualitas pelaporan keuangan SKPA bernilai 16.492. Pada 
tingkat koefisien masing-masing variabel memiliki koefisien sebesar 0,254 pada variabel pemanfaatan teknologi, 0,181 pada variabel kompetensi SDM dan sebesar 0,173 pada variabel komitmen organisasi.

Dari hasil regresi ini juga dapat diketahui nilai rataan yang dihasilkan dengan melihat nilai $\mathrm{R}$ yang dihasilkan.

\section{Hasil R Square}

Model Summary

\begin{tabular}{|l|r|r|r|r|}
\hline Model & \multicolumn{1}{|c|}{$\mathbf{R}$} & R Square & \multicolumn{1}{c|}{$\begin{array}{c}\text { Adjusted } \mathrm{R} \\
\text { Square }\end{array}$} & $\begin{array}{l}\text { Std. Error of the } \\
\text { Estimate }\end{array}$ \\
\hline 1 & $.726^{\mathrm{a}}$ & .528 & .504 & 1.636 \\
\hline
\end{tabular}

a. Predictors: (Constant), KO, PT, KS

Sumber: Data Primer, 2019 (diolah)

Pengaruh Pemanfaatan Teknologi, Sumber Daya Manusia dan Komitmen Organisasi Terhadap Kualitas Laporan Keuangan

Dari pengujian dan analisis yang dilakukan (Tabel 4.5) maka dapat diketahui bahwa variabel bebas yang digunakan memiliki nilai Fhitung 21,973 pada nilai Ftabel yang ditentukan adalah 2,76. Dengan demikian dari teori yang telah dijabarkan sebelumnya, apabila nilai Fhitung lebih besar daripada nilai Ftabel maka dapat disimpulkan bahwa variabel bebas yang digunakan berpengaruh simultan pada variabel terikat.

Berdasarkan hasil dari koefisien regresi (Tabel 4.6) dapat diketahui bahwa hasil pengujian koefisien korelasi menghasilkan nilai $\mathrm{R}$ yang bernilai 0,726 . Nilai $\mathrm{R}$ tersbut menunjukkan tingkat korelasi yang dihasilka antara variabel independen dan dependen sebesar $72,6 \%$. Hal ini menunjukkan bahwa tingkat besaran hubungan yang dihasilkan variabel bebas terhadap variabel terikat.

Pada tingkat koefisien determinasi, data yang digunakan menghasilkan besaran sebesar 52,8\%. Ini menandakan bahwa variabe bebas yang digunakan memiliki besaran hubungan pada variabel terikat sebesar 52,8\% dan sisanya merupakan faktor yang tidak digunakan dalam penelitian. Masing-masing besaran koefesien yang dihasilkan adalah sebagai berikut:

$$
\begin{array}{ll}
\text { - } & \mathrm{X} 1=0,254 \\
\text { - } & \mathrm{X} 2=0,181 \\
\text { - } & \mathrm{X} 3=0,173
\end{array}
$$

\section{Pengaruh Pemanfaatan Teknologi terhadap Kualitas Laporan Keuangan}

Hipotesis pemanfaatan teknologi berpengaruh terhadap kualitas pelaporan keuangan tidak dapat ditolak. Hal ini dapat dibuktikan dari hasil analisis yang telah dilakukan. Pemanfaataan teknologi memiliki besaran signifikansi sebesar 0,002 dan nilai ini lebih besar dari nilai $(\alpha)$ yang ditentukan sebesar 0,05 . Penggunaan dan juga pemanfaatan terhadap teknologi tidak hanya menjadi kewajiban bagi pemerintah daerah namun hal ini juga dapat menjadi pendorong bagi pemerintah daerah untuk lebih mengembangkan pemerintahan ke arah yang lebih baik. Penggunaan teknologi dalam mengelola keuangan merupakan hal yang penting untuk dilakukan mengingat semakin berkembang dan pesatnya teknologi saat ini maka dibutuhkan penyeimbang bagi pemerintahan untuk terus meningkatkan kinerjanya bagi publik. Percepatan proses pengolahan terhadap data-data transaksi yang dilakukan pemerintahan, penyajian laporan yang tepat, merupakan bukti dari pemanfaatan teknologi yang harus terus dikembangkan. Peraturan Pemerintah No.65 Thn 2010 telah menyatakan bahwa teknologi wajib dimanfaatkan dan dikembangkan bagi setiap instansi pemerintah.

Penelitian ini sama dan juga sejalan dengan hasil penelitian terdahulu yang dilakukan oleh Zualiarti (2012) da juga Yosefrenaldi (2013) yang menemukan bahwa pemanfaaatan teknologi memiliki pengaruh yang positif terhadap kualitas laporan keuangan.

\section{Pengaruh Sumber Daya Manusia Terhadap Kualitas Laporan Keuangan}

Hasil dari analisis yang telah dilakukan mendapati bahwa variabel SDM memiliki tingkat signifikansi sebesar 0,002 yang dimana lebih besar dari nilai $(\alpha) 0,05$. Hipotesis awal yang menyatakan Kompetensi SDM berpengaruh terhadap kualias laporan keuangan tidak dapat ditolak. Komptensi SDM merupakan salah satu pilar penting bagi berjalannya suatu organisasi. Keahlian yang tepat dan sesuai bidangnya khususnya keahlian akuntansi dalam persolan keuangan menjadi hal yang penting untuk diperhatikan. Peningkatan efisiensi dan keterandalan laporan yang dihasilkan dapat terwujud apabila sumber daya yang dimiliki oleh setiap instansi telah 
sesuai dengan tugas yang diemban dan juga terus dilakukannya pelatihan dan perkembangan diri.

Penelitian ini menghasilkan hasil yang sama dengan penelitian Yudianti dan Erawati (2012) yang dimana menemukan bahwa kapasistas SDM memiliki pengaruh poitif terhadap kualitas informasi akuntansi. Yosefrinaldi (2013) dalam penelitiannya juga menemukan bahwa kapasitas yang dimiliki suatu SDM memliki pengaruh yang positif terhadap laporan keuangan.

\section{Pengaruh Komitmen Organisasi terhadap kualitas Laporan Keuangan}

Hasil dari analisis yang telah dilakukan mendapati bahwa variable komitmen organisasi memiliki tingkat signifikansi sebesar 0,020 yang dimana lebih besar dari nilai $(\alpha) 0,05$. Hipotesis awal yang menyatakan komitmen organisasi berpengaruh terhadap kualitas lapaoran keuangan tidak dapat ditolak. Komitmen merupakan sebuah bentuk rasa yang ingin terus saling mengembangkan antar individu maupun individu dengan organisasi. Komitmen berorganisasi bagi pemerintah daerah menjadi hal yang penting untuk dikembangkan sehingga setiap aparatur pemerintah yang dimiliki memiliki rasa untuk bertanggungjawab terhadap tugas dan tanggung jawab yang diberikan demi kepentingan instansi. Dalam penyusunan laporan keuangan hal ini juga menjadi suatu hal yang perlu diperhatikan, khususnya dalam menghasilkan laporan yang berkualitas dan andal, aparatur yang terkait selalu berupaya melakukan dan melaporkan informasi yang diperlukan demi kepentingan instansi.

Hasil penelitian ini sejalan dengan penelitian terdahulu yang dilakukan oleh Ratifah dan Ridwan (2012) pada penelitiannya Dalam Komitmen Organisasi Memoderasi Pengaruh Sistem Akuntansi Keuangan Daerah Terhadap Kualitas Laporan Keuangan menyatakan sistem akuntansi keuangan daerah memiliki pengaruh yang signifikan terhadap kualitas laporan keuangan, akan tetapi komitmen organisasi tidak berpengaruh signifikan apabila ditempatkan sebagai variabel moderasi.

\section{Kesimpulan, Keterbatasan Dan Saran Kesimpulan}

Dari hasil pengujian hipotesis dan pembahasan yang telah diuraikan pada bab-bab sebelumnya, maka dari penelitian ini dapat ditarik kesimpulan:

1. Pemanfaatan Teknologi berpengaruh positif terhadap Kualitas Laporan Keuangan Pemerintah Aceh. Hal tersebut dapat dibuktikan dengan nilai t-hitung yang lebih besar dari t tabel (3,203 > 2.001) dengan nilai signifikansi sebesar 0,002 lebih kecil dari 0,05 dan memiliki koefisien regresi bernilai positif sebesar 0,326 . Hal ini berarti bahwa pemanfaatan teknologi pada SKPA provinsi Aceh telah digunakan secara efektif dan efisien sehingga mempermudah dan mempercepat pekerjaan auditor yang membutuhkan teknologi untuk melakukan pekerjaan dengan cepat.

2. Sumber Daya Manusia berpengaruh positif terhadap Kualitas Laporan Keuangan Pemerintah Aceh. Hal tersebut dapat dibuktikan dengan nilai $\mathrm{t}$ hitung yang lebih besar dari t tabel $(3,181>$ 2.001) dengan nilai signifikansi sebesar 0,002 lebih kecil dari 0,05 dan memiliki koefisien regresi bernilai positif sebesar 0,332. Hal ini berarti semakin baik sumber daya manusia, maka semakin baik pula kemampuan pemerintah daerah dalam menghasilkan laporan keuangan yang berkualitas.

3. Komitmen Organisasi berpengaruh positif terhadap Kualitas Laporan Keuangan Pemerintah Aceh. Hal tersebut dapat dibuktikan dengan nilai $t$ hitung yang lebih besar dari $t$ tabel $(3,382>$ 2.001) dengan nilai signifikansi sebesar 0,020 lebih kecil dari 0,05 dan memiliki koefisien regresi bernilai positif sebesar 0,267 . Lembaga pemerintah yang memiliki komitmen dalam penyajian laporan keuangannya akan selalu berupaya untuk membuat laporan keuangan yang sesuai dengan aturan yang berlaku serta memiliki informasi yang berkualitas. Hal ini berarti semakin baik tingkat penerapan komitmen organisasi, maka akan meningkatkan kualitas laporan keuangan daerah.

4. Hasil uji hipotesis (uji F) menunjukkan bahwa secara bersama-sama (simultan) semua variabel bebas yang terdiri dari Teknologi informasi (X1), Sumber Daya Manusia (X2), Komitmen Organisasi (X3) dengan nilai F-hitung sebesar 
21.973 dengan nilai signifikansi Sebesar 0,000 dikarenakan secara simultan nilai signifikansi dari ketiga variabel bebas tersebut lebih kecil dari nilai alpha 0,05 , maka ketiga variabel bebas secara simultan berpengaruh signifikan terhadap Kualitas Laporan Keuangan Provinsi Aceh. Hasil analisis tersebut menerima hipotesis kelima yang menyatakan bahwa Teknologi Informasi, Sumber Daya Manusi dan Komitmen Organisasi secara simultan berpengaruh signifikan terhadap Kualitas Laporan Keuangan Pemerintah Aceh.

\section{Batasan Penelitian}

Penelitian ini pada hakikatnya memiliki beberapa batasan dalam menentukan hasil penelitiannya, yaitu:

1. Data penelitian ini diperoleh berdasarkan persepsi jawaban responden menggunakan kuesioner tanpa melakukan survei. Sulit bagi peneliti untuk mendapatkan jaminan bahwa semua responden akan mengembalikan kuesioner ini, karena kuesioner ini tidak dikembalikan hari itu. Kuesioner yang disediakan disimpan selama dua hari, sehingga ada beberapa SKPA yang tidak lengkap mengembalikan kuesioner yang disediakan.

2. Penelitian ini hanya menggunakan tiga variabel independen, yaitu penggunaan teknologi, kompetensi sumber daya manusia dan komitmen organisasi dalam melihat pengaruh kualitas laporan keuangan. Beberapa variable lain yang mungkin mempengaruhi kualitas laporan keuangan pemerintah daerah tidak diikut sertakan dalam penelitian ini

\section{Saran}

Berdasarkan beberapa keterbatasan penelitian yang ada, peneliti memberikan beberapa saran kepada peneliti selanjutnya :

1. Untuk menguatkan dan mendukung hasil penelitian ini, maka perlu dilakukan pengujian kembali untuk melihat konsistensi penelitian ini dengan penelitian terdahulu dan penelitian berikutnya. Seperti memperbaiki item-item pertanyaan dalam kuesioner atau penggunaan indikator yang berbeda untuk pengukuran setiap variabel.
2. Mempertimbangkan variabel-variabel lain yang diduga berpengaruh terhadap kualitas laporan keuangan pemerintah daerah.

3. Mengganti teknik pengumpulan data dari kuesioner menjadi wawancara ataupun teknik lainnya demi meminimalisir permasalahan subjektivitas dan keseriusan responden

\section{DAFTAR PUSTAKA}

Allen, N.J. dan J.P. Meyer. 1991. The Measurement and Antecedents ofAffective, Continuance and Normative Commitment to theOrganizational. Journal of Occupational Psychology. 63 (1): 1-18

Azhar. 2007. Faktor-faktor yang Mempengaruhi Keberhasilan Penerapan Permendagri Nomor 13 Tahun 2006 Pada Pemerintah Kota Banda Aceh. Tesis. Pascasarjana Universitas Sumatera Utara. Medan.

Darwanis \& Desi Dwi Mahyani. 2009. Pengaruh kapasitas sumber daya manusia, pemanfaatan teknologi informasi dan pengendalian intern akuntansi terhadap keterandalan pelaporan keuangan pemerintah daerah. Jurnal Telaah \& Riset Akuntansi. Vol.2. No. 2 Hal. 133-151.

Fathoni, Abdurrahmat. 2006. Organisasi dan Manajemen Sumber Daya Manusia. Jakarta : Roneka Cipta.

Ghozali, Imam, 2013. Aplikasi Analisis Multivariat dengan Program IBM SPSS 21. Edisi 7, Penerbit Universitas Diponegoro, Semarang.

Hahn, M., Lawson, R., and Lee, Y. G. 1992. The Effects of Time Pressure and Information Load on Decision Quality. Psychology and Marketing, 9 (5): 365-378.

Ifa Ratifah dan Mochammad Ridwan. (2012). Komitmen Organisasi MemoderasiPengaruh Sistem Akuntansi Keuangan Daerah terhadap Kualitas LaporanKeuangan. Trikonomika Vol. 11, No. 1, Juni 2012

Ikatan Akuntansi Indonesia (2012), Standar Akuntansi Keuangan. Jakarta :Salemba Empat.

Indriasari, Desi \& Ertambang Nahartyo. 2008. Pengaruh Kapasitas sumberdaya manusia, Pemanfaatan Teknologi Informasi, Dan Pengendalian Intern Akuntansi Terhadap Nilai Informasi Pelaporan Keuangan Pemerintah Daerah (Studi Pada Pemerintah Kota 
Palembang dan Kabupaten Ogan Ilir). SNA. Politeknik Negeri Sriwijaya Palembang.

Kharis, Abdul. 2010. Pengaruh Kualitas Sumber Daya manusia Terhadap Pelaksanaan Sistem Pengendalian Intern pada PT. Avia Avian. Skripsi. UPN Veteran, Jawa Timur.

Kreitner dan Kinicki, 2013, Perilaku Organisasi, Salemba Empat, Jakarta.

Maksyur, Noprial Valenra. 2015. Pengaruh Kualitas Sumber Daya Manusia, Komitmen Manajemen, Sistem Pengendalian Intern, dan Pemanfaatan Teknologi Informasi, terhadap Kualitas Laporan Keuangan (Studi Empiris Pada SKPD Kabupaten Indragiri Hulu). JOM FEKON Vol.2 No. 2 Oktober 2015

Mardiasmo. 2002. Telaah Kritis Terhadap Upaya Aktualisasi Kebutuhan Sistem Akuntansi Keuangan Pemerintah Daerah. JAAI. UGM. Yogyakarta.

Mulyadi. 2010. Sistem Akuntansi. Jakarta. Salemba Empat.

Ramadhan, Shahrul. 2015. Pengaruh Kompetensi Sumber Daya Manusia Pengelolaan Keuangan, Pengendalian Intern, Teknologi Informasi dan Komitmen Organisasi Terhadap Kualitas Laporan Keuangan Pada Satker Kemerintrian Pekerjaan Umum Direktorat Jenderal Cipta Karya Provinsi Kepri. Jurnal Universitas Maritim Raja Ali Tanjungpinang.

Republik Indonesia, Peraturan Pemerintah Nomor 56

Tahun 2005 tentang SistemInformasi Keuangan

Daerah ,Peraturan Pemerintah No.71 Tahun 2010.

Tentang Standar Akuntansi Pemerintahan , Undang-Undang RI No. 43 Tahun 1999 tentang pokok-pokok kepegawaian.

Salancik. 1977. Commitment is Too Easy Organizational Dynamics : 6, pp. 62-80.

Silviana. 2013. Hubungan Penerapan Sistem Informasi Akuntansi Terhadap Kualitas Laporan Keuangan Pemerintah Daerah.E-Jurnal UNS

Sarjono, Haryadi., dan Julianita, Winda. (2011). SPSS vs LISREL: SebuahPengantar, Aplikasi untuk Riset. Penerbit Salemba empat, Jakarta.

Syarifudin, Akhmad. 2014. Pengaruh Kompetensi SDM dan Peran Audit Intern terhadap Kualitas Laporan Keuangan Pemerintah Daerah dengan Variabel Intervening Sistem Pengendalian
Internal Pemerintah (Studi Empiris pada Pemkab Kebumen). Jurnal Fokus Bisnis, Vol. 14, No 02, bulan Desember 2014.

Wati, K. Desianan., N. Trisna Herawati dan Ni. K. 2014. Pengaruh Kompetensi Sdm, Penerapan Sap, Dan Sistem Akuntansi Keuangan Daerah Terhadap Kualitas Laporan Keuangan Daerah. e- Journa. Volume 2 No: 1. Tahun 2014.. Ejournal

Yosefrinaldi. 2013. Pengaruh Kapasitas Sumber Daya Manusia dan Pemanfaatan Teknologi Informasi Terhadap Kualitas Laporan Keuangan Pemerintah Daerah Dengan Variabel Intervening Sistem Pengendalian Intern Pemerintah (Studi Empiris Pada Dinas Pengelolaan Keuangan dan Aset Daerah Se-Sumatera Barat). Fakultas Ekonomi. Universitas Negeri Padang. Padang.

Yudianta, Erawati, 2012, Pengaruh Sumber Daya Manusia TeknologiInformasi dan Pengendalian Intern terhadap Kualitas Laporan Keuangan,EJurnal AkuntansiUniversitas Udayana.

Zuliarti. 2012. Pengaruh Kapasitas Sumber Daya Manusia, Pemanfaatan Teknologi Informasi, dan Pengendalian Intern Akuntansi Terhadap Nilai Informasi Pelaporan Keuangan Pemerintah Daerah : Studi Pada Pemerintah Kabupaten Kudus. Skripsi. Universitas Muria Kudus. Kudus. 